\title{
Intoleransi dan Radikalisme Agama: Konstruk LSM tentang Program Deradikalisasi
}

\author{
Endang Supriadi, ${ }^{*}$ Ghufron Ajib, Sugiarso Sugiarso \\ Program Studi Sosiologi, Fakultas Ilmu Sosial dan Ilmu Politik (FISIP), Universitas \\ Islam Negeri Walisongo, Semarang - Indonesia
}

\begin{abstract}
Reformation-era opened the opportunities for political freedom and the development of religious life among the Islamic community in Indonesia. It can be seen in the strengthening of the identity and the movements of religious groups outside the mainstream religious groups, namely radicalism. Acceptance of different narratives based on religious sentiments is shown in the public space by building a distinction between "us" and "them". There is a need for an antidote toward radical understanding that resulted in acts of terror naming the deradicalization. By qualitative methods, this study indicated that during the nine years of the establishment of the National Counterterrorism Agency (BNPT) the programs are still static because the program has not been able to minimize or even eliminate radical understanding that led to acts of terror. All elements of civil society must strengthen the deradicalization program of BNPT. Both NGOs (Wahid Institute and SETARA Institute) stated that the process of deradicalization was not only on individual problems, but the social environment also played an active role. It is the state that has the ability in the process of deradicalization, but the state must involve civil society.
\end{abstract}

Era reformasi membuka peluang bagi kebebasan politik dan perkembangan kehidupan keagamaan masyarakat Islam di Indonesia. Hal ini dapat dilihat dengan semakin menguatnya identitas dan gerakan kelompok keagamaan di luar mainstream kelompok keagamaan, yakni radikalisme. Penerimaan narasi berbeda berdasarkan sentimen agama ditunjukkan diruang publik dengan membangun pembeda antara "kami" dan "mereka". Perlu adanya penangkal paham radikal yang berujung aksi teror yakni deradikalisasi. Penelitian ini menggunakan metode penelitian kualitatif. Hasil dari penelitian ini menunjukkan bahwa selama 9 tahun berdirinya Badan Nasional Penanggulangan Terorisme (BNPT) program-programnya masih belum mampu meminimalisir atau bahkan menghilangkan paham radikal yang berujung kepada aksi teror. Semua elemen masyarakat sipil harus memperkuat Program deradikalisasi BNPT. Kedua LSM (Wahid Institute dan SETARA Institute) menyatakan bahwa proses deradikalisasi tidak semata pada persoalan individu, tetapi lingkungan sosial juga berperan aktif. Dalam hal ini negaralah yang memiliki kemampuan dalam proses deradikalisasi, akan tetapi negara harus melibatkan masyarakat sipil.

Keywords: deradicalization; intolerance; NGOs; radicalism; terrorism

*Korespondensi Penulis: Endang Supriadi (endang.supriadi@walisongo.co.id) Program Studi Sosiologi, Fakultas Ilmu Sosial dan Ilmu Politik (FISIP), Universitas Islam Negeri Walisongo, Jl. Prof. Dr. HAMKA, Km. 2 Ngaliyan Semarang, Jawa Tengah 50185. 


\section{Pendahuluan}

Terbukanya kran kebebasan politik dan demokrastisasi setelah tumbangnya rezim Orde Baru bukan hanya memberikan ruang bagi munculnya berbagai macam ekspresi yang dibangun berdasarkan sentimen dan identitas primordial, tetapi juga membuka jalan bagi ekspansi radikalisme. Sejalan dengan konsolidasi demokrasi yang tengah berlangsung, yang ditandai dengan peran negara tertib sipil melalui program deradikalisasi, aparat hukum menangkap, menetralisir, dan menjinakkan anggota kelompok radikal hingga berhasil secara signifikan melemahkan jaringan radikalisme (Belarminus 2016; Hikam 2016).

Secara organisatoris jaringan radikalisme sudah jauh melemah, namun bukan berarti akhir dari ancaman radikalisme di Indonesia. Agensi ideologi radikal terbukti mempunyai kemampuan beradaptasi atau mengubah diri untuk bertahan. Agensi tersebut bahkan berperan dalam memperluas sirkulasi ideologi radikal dari kalangan minoritas (terbatas) yang sangat kecewa dengan keadaan kepada mereka yang memiliki tingkat kekecewaan lebih rendah.

Hasil survei Pusat Pengkajian Islam dan Masyarakat (PPIM) UIN Jakarta di tahun 2017 menemukan ada 34,3\% responden yang terdiri dari anak muda setuju bahwa jihad adalah gerakan melawan non-Muslim. Sedangkan tindakan kekerasaan agama dipicu salah satunya oleh intoleransi dan dapat berubah menjadi terorisme sebagai bentuk paling akhir (Perkasa 2016). Survei dari Wahid Institute (2020) menggambarkan bahwa sikap intoleransi di Indonesia cenderung meningkat dari 46\% hingga sekarang menjadi 54\%. Kecenderungan meningkat ini di pengaruhi oleh beberapa faktor di antaranya; kontestasi politik, ceramah yang bermuatan ujaran kebencian, dan unggahan bermuatan ujaran kebencian di media sosial. Meningkatnya sikap intoleransi berakibat kepada tindakan merusak atau berdampak kepada kelompok lainnya di tengah kehidupan bermasyarakat di Indonesia.

Data di atas menunjukkan bahwa tren intoleransi dan radikalisme di Indonesia meningkat dari waktu ke waktu. Salah satu faktor yang berdampak besar dari meningkatnya intoleransi dan radikalisme adalah ujaran kebencian melalui media sosial. Meningkatnya intoleransi dan radikalisme di Indonesia tidak dibarengi dengan tren meningkatnya aksi terorisme. Sejarah mencatat bahwa aksi terror seringkali dilakukan ketika bulan Ramadhan. Setidaknya tercatat secara berurutan misalnya, pada 5 Juli 2016 kasus bom bunuh diri di Mapolres Solo, yang terjadi menjelang Ramadhan; pada 23 Mei 2017 terjadi peledakan bom di Kampung Melayu; pada 13 Mei 2018 terjadi peledakan bom gereja Surabaya, hari berikutnya ada bom di Mapolrestabes Surabaya, dua hari setelahnya terjadi serangan teror di Mapolda Riau; dan pada 3 Juni 2019 terjadi serangan bom di Pos Polisi Kartasura, Jawa Tengah (Azanella 2018; Tim Liputan CNN 2019b).

Temuan dari Center for Religious and Crosscultural Studies (CRCS) (2017) menunjukkan keberhasilan kelompok radikal dalam menyebarkan ideologinya. Adapun cara-cara yang digunakan adalah dengan pola baru misalnya, pola reproduksi jaringan paham radikal sering kali memanfaatkan tindakan permisif masyarakat terhadap ideologi radikal yang terjadi ketika persoalan-persoalan struktur, kemiskinan, pengangguran dan keterbelakangan semakin menghimpit kehidupan mereka (Bagir 2018). 
Kasus bom bunuh diri yang dilakukan oleh M. Syarif pada tahun 2011 di masjid Mapolresta Cirebon, menunjukkan bahwa pelaku sebelumnya aktif dalam Gerakan Anti Pemurtadan dan Aliran Sesat (GAPAS) yang eksis di tengah masyarakat Cirebon. M. Syarif kemudian direkrut oleh jaringan lama dari sebuah kelompok radikal untuk tujuan menerapkan pola dan strategi baru yang dikenal dengan istilah "istighlayat", yakni serangan dalam skala kecil dan bersifat independen dari kelompok radikal yang lebih besar (Asrori 2017).

Perubahan sosial yang dialami kaum muda bersama dengan tingginya persaingan merebutkan lapangan kerja menjadikan kaum muda rentan terhadap pengaruh paham radikal. Hasil temuan dari Lembaga Kajian Islam Perdamaian (LaKIP) pada tahun 2011 dari 100 sekolah tingkat SMP dan SMA Umum di daerah Ibu Kota terdapat 48,9\% menyatakan setuju atas aksi-aksi kekerasan yang berjubah keagamaan (Tim Liputan BBC 2011; Tim Liputan CNN 2019a). Temuan dari PPIM UIN Jakarta (2017) menunjukkan bahwa $53,74 \%$ responden yang terdiri dari siswa/ mahasiswa setuju bahwa orang Yahudi itu musuh Islam. Temuan lainnya adalah sikap dan simpati mereka terhadap pelaku tindakan radikal. Hal tersebut tidak lepas dari derasnya gelombang aktivis Islamis yang terus-menerus mensosialisasikan keberadaannya, mensosialisasikan eksklusivitas hingga pada sikap intoleransi baik di sekolah maupuan tingkat universitas (Iswanto 2018).

Pelanggaran atas kebebasan beragama semakin meningkat bersama dengan berjalannya waktu. Data SETARA Institute menunjukkan bahwa di tahun 2014 ada 134 peristiwa, tahun
2015 ada 197 peristiwa, dan pada tahun 2016 meningkat menjadi 203 peristiwa (Halili 2016, 2017). Data tersebut menunjukkan bahwa kebijakan, tindakan aktif negara, aktor-aktor intoleran dan konsolidasi masyarakat sipil toleran memperlihatkan bahwa faktor-faktor pemicu pelanggaran yang terjadi tidak banyak berubah. Peristiwa ini dijadikan sebagai dasar bagi pengamat untuk melihat lanskap keagamaan di bumi pertiwi yang sedang menuju kepada yang lebih konservatif (Fealy 2008).

Sejarah islamisme menunjukkan keterkaitan erat antara mobilisasi gerakan radikal dengan perubahan lanskap sosial politik yang bersifat temporal. Indonesia pernah diwarnai gerakan Darul Islam yang telah menginspirasi persemaian ideologi Islamis yang berhaluan "menentang negara" (van Bruinessen 2002). Pengaruh globalisasi turut mempercepat berkembangnya paham radikalisme. Globalisasi berimplikasi terhadap penyebaran paham radikalisme karena bukan saja mengancam nilai-nilai tradisional masyarakat, tetapi mempersempit jarak spasial maupun temporal antara satu negara dengan negara lainnya (Rabasa dan Benard 2014).

Melihat beberapa kasus di atas, penulis berasumsi bahwa negara dalam hal ini BNPT selama ini belum terlihat maksimal peranannya dalam menuntaskan kasus-kasus kekerasan yang mengatasnamakan agama yang ditunjukkan dengan aksi teror. Meskipun BNPT sudah merilis program unggulannya yakni program sinergi antarkementerian dan lembaga, namun kasus kekerasan yang berujung teror atas nama agama masih terjadi. Penulis beranggapan bahwa Negara belum mampu menuntaskan permasalahan kekerasan sehingga jaminan keamanan bagi 
kelompok minoritas dalam persoalan kemerdekaan dalam menjalankan aktivitasnya sering dikalahkan dengan keinginan dari kelompok mayoritas. Negara perlu membangun komunikasi yang baik terhadap semua kelompok dan golongan yang berbeda. Sebagai warga negara dan umat beragama yang hidup di lingkungan multiagama seperti Indonesia seharusnya dapat membangun atmosfir komunikasi yang konstruktif.

Dalam tulisan sebelumnya, isu tentang fenomena radikalisme agama telah menjadi kajian yang menarik bagi para sarjana, akademisi, dan peneliti. Zuly Qodir (2012) mengkaji mengenai fenomena radikalisasi agama di dunia pendidikan baik pada tingkat menengah atas maupun perguruan tinggi dan menyimpulkan bahwa lembaga pendidikan harus memberikan pemahaman secara menyeluruh tentang keragaman agama yang ada di Indonesia, karena bagian dari realitas sosiologis.

Abdul Munip (2012) juga menjelaskan bahwa fenomena radikalisme agama tumbuh subur di dunia pendidikan. Perlu adanya kerjasama dan mensinergikan antar elemen masyarakat baik yang ada di dunia pendidikan maupun di luar, sehingga paham-paham radikal tidak subur di dunia pendidikan. Karena mereka perlu dirangkul bukan dihindari serta diajak kembali ke jalan ajaran Islam yang penuh dengan kedamaian dan kesejukan.

Masih terkait dengan radikalisme agama di lingkungan sekolah. Taslim Syahlan (2015) menyimpulkan bahwa peran sekolah dalam hal penanggulangan paham radikalisme sangat penting, karena keberadaan kaum muda yang dijadikan sasaran empuk bagi paham ini. Dalam hal ini pihak sekolah harus memberikan pemahaman yang konfrehensip terkait dengan ajaran Islam; metode pembelajaran agama dengan mengedepankan dialog; pihak sekolah harus kooperatif terhadap seluruh kegiatan keagamaan; dan harus dikenalkan serta penerapan pendidikan multikultural.

Terkait dengan deradikalisasi, Panji Futuh Rahman (2016) mengatakan bahwa penerapan materi deradikalisasi di lembaga ekstrakulikuler keagamaan sangat diperlukan untuk menanggulangi radikalisme.

Pada penelitian Abu Rokhmad (2012) ditemukan bahwa di sekolah-sekolah terdapat unit-unit kajian Islam yang berkembang baik namun tidak ada jaminan adanya kekebalan dari radikalisme karena proses belajarnya diserahkan kepada pihak ketiga (mentor dari luar sekolah). Terkait deradikalisasi, Abu Rokhmad (2014) mengkaji tentang pandangan sosok kiai terkait dengan program deradikalisasi dan kajian tersebut menyebutkan bahwa peran kiai sangat dibutuhkan untuk menanggulangi paham radikal yang semakin masif pergerakannya di masyarakat.

Pada sisi lain, Endang Supriadi (2018) menyatakan bahwa di era desentralisasi demokrasi dibutuhkan peran dari semua kalangan dan dalam membendung radikalisme dibutuhkan adanya program deradikalisasi yang melibatkan semua elemen, baik pemerintah maupun masyarakat sipil dengan metode pendekatan soft power dan hard power. Dalam tulisannya, pelibatan masyarakat sipil sangat dibutuhkan dalam penanggulangan radikalisme dan strategis untuk terus dikembangkan di Indonesia dalam era demokratisasi. 
Artikel ini ditulis untuk mengisi ruang analisis terkait dengan proses dan konstruk lembaga swadaya masyarakat terhadap program deradikalisasi pemerintah.

Pelibatan elemen masyarakat sipil perlu dikembangkan termasuk Lembaga Swadaya Masyarakat (LSM). Dalam era keterbukaan seperti sekarang ini, LSM dimungkinkan untuk memiliki hubungan yang baik dengan pemerintah karena LSM memiliki sifat yang independen, fasilitator, kerjasama, dan kooperatif. LSM sebagai salah satu bagian dari organisasi masyarakat merupakan unsur potensial untuk menciptakan civil society. Hal lain yang penting adalah pemberdayaan civil society yang dikerjakan dengan usaha-usaha penguatan masyarakat grassroots melalui berbagai aktivitas pendampingan dan pembelaan atas hak-hak rakyat Dalam kasus penanggulangan paham radikal pemerintah dalam hal ini BNPT tidak cukup hanya memainkan perananya sendiri, tetapi harus melibatkan LSM. Dengan demikian, proses penanggulangan paham radikal yang dilakukan dengan program deradikalisasi dapat berjalan dengan maksimal dan tidak ada lagi peristiwa kekerasan yang merugikan masyarakat sipil.

Memperlihatkan kompleksitas masalah di atas yakni intoleransi, radikalisme dan aksi terorisme yang mengancam Indonesia masa kini, penelitian ini melihat bagaimana proses dan efektivitas program deradikalisasi yang dijalankan oleh pemerintah dalam menangkal paham radikal di Indonesia; Bagaimana konstruk Wahid Institute dan SETARA Institute terhadap program deradikalisasi pemerintah. Kedua LSM tersebut merupakan representasi dari masyarakat sipil yang juga memiliki andil dalam mencegah radikalisme agama dan persoalan intoleransi agama.

\section{Menakar Proses dan Efektivitas Program Deradikalisasi}

Fenomena radikalisme dalam hubungannya dengan keagamaan yang meliputi radikalisme dan aksi radikal dewasa ini sangat menarik untuk dicermati dan penting untuk diperhatikan lebih serius. Dinamika dalam kehidupan sosial merupakan suatu hal yang terus terjadi setiap saat. Kehidupan beragama dalam masyarakat juga mengalami gelombang dinamika yang cepat. Sikap dan perilaku keberagamaan dalam masyarakat menampakkan adanya pola moderat dan radikal. Memahami makna radikalisme baik sebagai paham, gerakan, dan aksi dapat berimplikasi luas dalam dinamika kehidupan di masyarakat. Implikasi itu bisa dalam bentuk kegiatan yang mengganggu inovasi dan perkembangan stabilitas ekonomi-politik, serta sosial-budaya atau bahkan berimbas pada rasa kekhawatiran yang terus menerus ada di masyarakat, serta tidak adanya rasa aman dan nyaman dalam kehidupan masyarakat secara luas.

Program deradikalisasi yang dilakukan BNPT dalam pelaksanaannya berada di bawah tanggung jawab Deputi I dalam bidang pencegahan, perlindungan dan deradikalisasi. Ada tujuh pendekatan yang saling terkait satu dengan lainnya guna mendapatkan hasil yang komprehensif dalam pelaksanaan program deradikalisasi. Tujuh pendekatan tersebut diantaranya; pendekatan agama, psikologi, sosial budaya, ekonomi, hukum, 
politik, dan teknologi informasi (Zuhri 2017). Seperti yang tertuang di dalam Perpes No. 46 Tahun 2010, bahwa BNPT harus melakukan koordinasi dengan lembaga pemerintahan dan non-pemerintahan dalam pelaksanaan program deradikalisasi. Program deradikalisasi BNPT dirancang untuk merekonstruksi pemahaman bersama yang bersifat radikal. Program tersebut juga dilaksanakan secara bertahap agar tujuannya tercapai secara efektif.

Ada dua klasifikasi pelaksanaan program yang dilaksanakan oleh BNPT yang penting untuk dikaji dalam konteks ini. Yang pertama adalah program deradikalisasi di dalam lapas. Program ini dilakukan melalui tahapan identifikasi, rehabilitasi, reedukasi, pengamatan, dan evaluasi. Program pertama ini diperuntukkan bagi narapidana kasus terorisme yang sedang menjalani masa tahanan. Di dalam lapas bagi yang telah berstatus narapidana, dan di luar lapas bagi mereka yang telah kembali ke dalam masyarakat, namun masih sangat rapuh dan mudah tergoda untuk kembali ke dalam jaringan lama (Mahyani 2019). Menurut penulis, program deradikalisasi di lapas lebih banyak menekankan pada reedukasi ideologi negara, dinilai tidak memberikan perubahan berarti dalam perubahan pola pikir narapidana terorisme.

Pembinaan dari pamong sebagai wali dari para narapidana kasus terorisme terlihat kurang maksimal, karena masih banyak pamong yang belum dibekali oleh pembangunan kapasitas, baik kapasitas sebagai pendamping maupun orang yang menangani narapidana dengan resiko tinggi. Melihat beberapa program di dalam lapas yang dilakukan BNPT kerjasama dengan lembaga pemasyarakatan masih ditemukan kendala, sehingga terlihat kurang maksimal, maka perlu adanya evaluasi secara menyeluruh di lembaga pemasyarakatan kasus teroris.

Program deradikalisasi di dalam lapas yang bersifat inklusif, misal pelatihan manajemen dan pelatihan manajemen kehidupan merupakan praktek yang terbaik karena sifatnya yang partisipatif dan mengajarkan keterampilan yang sangat dibutuhkan baik ketika berada dalam lembaga pemasyarakatan maupun ketikan menjalani reintegrasi sosial (Firdaus 2017). Direktur deradikalisasi Badan Nasional Penanggulangan Terorisme (BNPT) yakni Irfan Idris mengakui bahwa selama ini berbagai pihak lebih memusatkan perhatian pada bagaimana menangani narapidana berisiko tinggi, tapi melupakan nasib dan pengembangan sipir serta para staf lembaga pemasyarakatan (Idris 2016) Pengembangan sipir dan staf di lapas sangat diperlukan. Salah satunya untuk mencegah agar mereka tidak terpengaruh oleh ajaran radikalisme dan terorisme tersebut.

Kedua, program deradikalisasi di luar lapas. Program ini diperuntukkan bagi mantan narapidana teroris, dan keluarganya yang rentan terhadap paham-paham radikal. Program ini dilakukan untuk membentuk kemandirian ekonomi dari keluarga narapidana terorisme, proses resosiliasi atau reintegrasi mantan narapidana terorisme yang telah berhasil terderadikalisasi kedalam lingkungan masyarakat sosial dan pencegahan agar nantinya mantan narapidana terorisme tidak kembali melakukan aksi teror. Salah satu program deradikalisasi diluar lapas yakni kewirausahaan. Program ini 
harus dijalankan secara teliti ketika para mantan narapidana teroris kembali ke masyarakat untuk mengangkat kehidupan ekonomi mereka. Karena jika tidak disiapkan secara matang, program tersebut juga akan dinilai gagal. Perlu adanya koordinasi antar lembaga untuk memperkuat program deradikalisasi yang dijalankan oleh BNPT.

Awal diperkenalkan program deradikalisasi, banyak masyarakat yang tidak memahaminya sehingga kesimpulan sepihak pun dihembuskan melalui media sosial, bahwa deradikalisasi dimaknai sebagai deislamisasi. Deradikalisasi semangatnya senafas dengan tujuan Tuhan menurunkan syarìat, bukan sebaliknya seperti yang dipertahankan oleh kelompok yang tidak mau memahami, menolak untuk mendukung mesti telah paham dan hanya merasa paham. Di sini ketika adanya konfigurasi sikap masyarakat terhadap upaya pembinaan bagi sebagian masyarakat yang telah terinfiltrasi paham radikal anarkis, menjadi tantangan bagi pemerintah (Isnawan 2018).

Strategi deradikalisasi yang bertujuan menyebarkan dakwah dan tarbiyah kepada seluruh masyarakat dengan melibatkan masyarakat sipil sebagai ujung tombak dan garda terdepan dalam membentengi wilayah NKRI. Dalam memahami dan memaknai program deradikalisasi dengan menggunakan pendekatan humanis secara holistik, komprehensif, integral, dan akulturatif, menuntut perhatian serius dari seluruh lapisan masyarakat dan segenap komponen bangsa Indonesia. Setiap individu mempunyai kapasitas dan skill sebagai modal manusianya untuk dijadikan sebagai duta deradikalisasi yang mam- pu membina, merangkul dan memberdayakan masyarakat di lingkungan masing-masing.

Adapun efektivitas program deradikalisasi selama ini masih belum begitu efektif. Selama ini pelaksanaan program deradikalisasi dan pencegahan, BNPT melaksanakan kegiatan dengan kalangan moderat dan berharap mereka dapat melalukan syiar/dakwah dan upaya-upaya mencegah radikalisme-terorisme di lingkungan mereka. Target-target tertentu seperti aktivis penegakkan Syariat Islam, Khilafah Islamiyah serta para pendukung simpatisan mereka belum tersentuh secara masif dan efektif. Kelompok yang menginginkan negara berdasarkan syariah yang selama ini menyerang pemerintah dan menuduh negara sebagai state terrorisme yang seharusnya menjadi perhatian dari pemerintah untuk bisa membendung paham radikal di Indonesia.

Sejak tahun 2012, BNPT gencar membangun kapasitas berbagai elemen pemerintah dan non pemerintah di seluruh provinsi di Indonesia dan menyatukan mereka dalam forum yang di sebut Forum Komunikasi Pencegahan Terorisme (FKPT). Diharapkan FKPT menjadi kepanjangan tangan BNPT dalam bidang pencegahan dan deradikalisasi. Dalam prakteknya, FKPT sangat tergantung pada figur pengurus di dalamnya dan komitmen dukungan pemerintah daerah dan tentu saja pihak BNPT sendiri. Dalam praktekpraktek penanganan deportan dan returnee ISIS, bahkan untuk menangani pada mantan teroris kita hampir tidak mendengar peranan FKPT di daerah (Rauf 2018). Menurut penulis instrumen kesiapsiagaan nasional melalui FKPT tidak berjalan secara efektif. Seolah-olah yang dilakukan 
FKPT sebatas menggugurkan kewajiban yang diembannya sebagai bidang pencegahan dan deradikalisasi di daerah.

Rendahnya mutu hasil program, dari beberapa sumber yang pernah terlibat dalam program BNPT, menyebutkan bahwa implementasi program yang dilaksanakan BNPT lebih banyak dilaksanakan sekedar formalisasi administrasi (Suarda 2016). Sebagai contoh adalah program penelitian tentang deradikalisme di daerah. Program ini sebenarnya menarik dan menjanjikan, namun para peneliti di berbagai daerah yang dilibatkan tidak memiliki kompetensi yang memadai dalam penelitian. Ini berakibat pada kurangnya keseriusan penggalian persoalan, fokus kegiatannya. Persoalan lain adalah transparanan proses kerja serta pendanaannya. Pelaksanaan program semacam ini menjadikan program deradikalisasi menjadi kurang efektif karena basis data yang diperoleh kurang dapat dipertanggungjawabkan.

Adapun pelaksanaan deradikalisasi dilakukan secara bertahap dengan hasil dan rencana yang tentunya berbeda. Program deradikalisasi dilaksanakan secara sistematis meliputi tahapan identifikasi, rehabilitasi, reedukasi, dan resosialisasi yang ditujukkan bagi napi terorisme, keluarga, dan beserta jaringannya. Tahapan tersebut diharapkan menjadi kesinambungan program deradikalisasi di Indonesia. Proses pencegahan terorisme adalah program yang harus didasarkan pada fakta, data, pendekatan terukur yang pada akhirnya harus dilaksanakan melalui kerja sama yang komprehensif antar lembaga (Belarminus 2016; Hikam 2016).

Tahapan pada Tabel 1 menggambarkan bahwa program deradikalisasi bukan hanya ditujukan kepada para teroris yang ditahan atau telah direhabilitasi, termasuk keluarga mereka, tetapi lebih luas lagi. Deradikalisasi yang digalakkan oleh BNPT perlu ditujukan kepada semua lapisan masyarakat sehingga mereka mampu medeteksi sedini mungkin adanya bahaya atau ancaman ideologis yang disebarkan oleh para tokoh, pendukung, atau simpatisan gerakan radikal.

Keterlibatan masyarakat sipil dan elemen masyarakat lain sudah menjadi keniscayaan dalam program deradikalisasi. Deradikalisasi menjadi program yang diprioritaskan dalam penanggulangan paham radikal dengan pendekatan keamanan dan penegakan hukum. Jika dilihat dari tujuan dari program deradikalisasi dan dapat dilaksanakan dengan cara-cara yang

Tabel 1.

Tahapan Program Deradikalisasi di Indonesia

\begin{tabular}{cll}
\hline No. & Tahapan & Sasaran \\
\hline 1 & Identifikasi & Tersangka, keluarga, dan jaringan \\
2 & Rehabilitasi & Napi teroris dan keluarga napi \\
3 & Reedukasi & Napi teroris dan keluarga napi \\
4 & Resosialisasi & Napi teroris, mantan napi, keluarga napi, dan masyarakat \\
\hline
\end{tabular}

Sumber: Buku Merintis Jalan Mencegah Teroris: Sebuah Bunga Rampai (Bakti 2014) 
benar dan tepat dapat dipastikan akan meminimalisir atau bahkan menghilangkan paham radikal yang berujung pada aksi terorisme. Tentu dengan cara-cara yang preventif dan humanis serta pendekatan dialog dengan para napiter, keluarga, kerabatanya, hingga orang-orang sekitarnya atau bahkan orang yang terindikasi paham radikal (Belarminus 2016; Hikam 2016).

\section{Menyoal Program BNPT dalam Menangkal Radikalisme}

Secara kelembagaan, pemerintah telah membentuk BNPT untuk melakukan penanggulangan terorisme. Badan ini menganalisa aturan, memprioritaskan program deradikalisasi dan menyusun strategi dengan mengedepankan rasa kemanusiaan dalam upaya pencegahan ideologi radikal anarkis di masyarakat (Armenia 2016).

Program deradikalisasi yang dilakukan BNPT selama 9 tahun belum begitu menampakkan hasilnya, karena dimasyarakat masih ditemukan paham radikal yang berujung pada aksi terorisme. Perjalanan selama 9 tahun tidak mudah untuk meminimalisir atau mengkaunter paham radikal yang berujung aksi teror. Data yang penulis sampaikan di atas memberikan sinyal bahwa kebaradaan BNPT masih stagnan dan harus diperkuat oleh semua elemen masyarakat sipil.

Kehadiran BNPT selama 9 tahun lamanya tidak sepenuhnya dapat dukungan dari sebagian napiter dan keluarga, penolakan terhadap BNPT juga kerap dilontarkan oleh para mantan teroris dan para ikhwan jaringan mereka. Berbagai kegiatan yang dilakukan BNPT yang dimaksudkan untuk tujuan-tujuan pencegahan, de- radikalisasi, kontra terorisme menimbulkan resistensi di antara mereka. Ada pula yang mengalami kekecewaan yang mendalam. Misal berbagai kalangan/ormas di luar Nahdatul Ulama (NU) dan Muhammadiyah, merasa enggan, mau atau tidak mau mendukung program BNPT. Hasil riset yang dilakukan Solahudin menunjukkan bawah apa yang sudah dilakukan BNPT selama tahun 2013 hingga 2018 serangan teror dan plot serangan mampu digagalkan dan hasilnya fluktuatif mulai dari tahun 2013 ada 22, tahun 2014 ada 7, tahun 2015 ada 23, tahun 2016 ada 20, tahun 2017 ada 24, dan tahun 2018 ada 25 (Solahudin 2013). Perolehan ini tentu menjadi perhatian pemerintah dan semua elemen masyarakat.

Tantangan yang secara objektif bahwa kondisi deradikalisasi yang dikerjakan BNPT selama ini banyak tokoh, ilmuan dan pengamat teroris memandang bahwa program deradikalisasi ini tidak pernah menyentuh akar permasalahan yang sejatinya. Faktanya bahwa program tersebut alih-alih hanya sebagai proyek untuk menghabiskan anggaran Negara. Sehingga wajar jika hampir tiap tahun masih terjadi aksi bom bunuh diri atau perusakan rumah ibadah. Menurut berbagai elemen masyarakat dan kedua LSM yang dijadikan lokus penelitian ini menjadi catatan berharga untuk BNPT sebagai pusat program deradikalisasi dan menjadi bahan evaluasi bagi pelaksana deradikalisasi agar lebih fokus pada pemberdayaan ekonomi semua yang menjadi sasaran. Perlunya transparansi dan akuntabilitas publik BNPT juga sejauh ini kerap dipertanyakan. Dengan demikian, jika semua elemen masyarakat bersatu padu saling mensuport yang dilakukan 
BNPT, tidak menutup kemungkinan kejadian-

kejadian kekerasan karena berbeda keyakinan, bom bunuh diri bisa dihilangkan di muka bumi Nusantara.

Persoalan radikalisme dan terorisme itu adalah persoalan yang maha kompleks, lintas sektor dan lintas keilmuan dan bahkan lintas benua. Pendekatannya mesti multi disiplin dan lintas bidang dengan pemahaman yang harus terintegrasi dan holistik. Tak kalah pentingnya adalah dukungan sumberdaya manusia yang memadai, dengan dukungan anggaran serta regulasi (perundangan) yang mengikat dan mudah dilaksanakan. Artinya, dari sisi regulasi, jelas perlu dipertimbangkan kembali urgensi dan relevansinya dengan perkembangan mutakhir.

Sumber daya manusia yang menanganinya yang menjadi back bone BNPT serta seragam fungsinya, jangan asal ambil, apalagi diwarnai oleh unsur nepotisme yang mengabaikan kualitas dan kompetensi (Dewi 2018). Oleh karena itu, peran BNPT sangatlah strategis untuk diletakan di atas sebagai "top manager" dari seluruh lembaga pemerintah dan non pemerintah serta masyarakat sipil, baik yang berasal dari dalam maupun luar negeri. Ada beberapa aspek yang perlu diperkuat yakni aspek kewenangan yang "memaksa" lembaga pemerintah dan non pemerintah (pusat maupun daerah), serta masyarakat sipil untuk melaksanakan berbagai program kegiatan di bawah supervisi, monitoring dan evaluasi oleh BNPT yang mencakup aspek pencegahan, penindakan, perlindungan, deradikalisasi dan kesiapsiagaam Nasional (Belarminus 2016; Hikam 2016). Oleh karena itu, penguatan terhadap BNPT harus terus berjalan beriringan dengan peningkatan pengawasan eksternal.

\section{Konstruk LSM terhadap Tindakan Intoleransi, Radikalisme, dan Terorisme di Indonesia}

\section{Akar Penyebab dan Penyebaran Benih Intoleransi, Radikalisme, danTerorisme}

Pasca reformasi banyak peristiwa yang tibatiba muncul di tengah kehidupan masyarakat. Dalam beberapa tahun terakhir ini, ada faktafakta peristiwa kekerasan yang terjadi dan berhubungan dengan agama. Kekerasan tersebut bisa saja menimpa kelompok-kelompok agama dengan dalih argumen pembelaan agama sebagai alat untuk penghinaan terhadap agama sebagai pemicu terjadinya sebuah kekerasan. Dalam hal ini, agama dijadikan sebagai cover konflik kepentingan yang sesungguhnya, akan tetapi dipermukaan yang muncul adalah konflik antar anak bangsa yang berbeda agama. Peristiwa kekerasan berbasis agama ini terjadi karena minimnya sikap toleransi.

Fenomena kekerasan berbasis agama berawal dari pemahaman yang eksklusif, mewujud menjadi sikap sosial yang intoleran, yang mengeras menjadi tindakan radikal yang memusuhi dan menyerang kelompok yang berbeda, kemudian menjadi teroris yang merusak tatanan kemanusiaan dan kehidupan umat manusia. Individu yang bertindak demikian atas keyakinan dirinya sebagai satu-satunya jalan kebenaran untukmendapatkan ridla Tuhan.

Akar penyebab ini, diakui atau tidak sudah lama terpendam sebelum reformasi. Hal ini menjadi logis ketika dibukanya kran demokrasi seluas mungkin dan resonansi gelombang nasional yang menjalar hingga ke daerah. Bermunculan tokoh-tokoh dan ormas Islam garis 
keras ketika Indonesia sedang menikmati kehidupan di alam demokrasi. Indonesia yang dikenal sebagai negara muslim terbesar di dunia tentu menjadi prioritas negara untuk ditundukkan. Dalam hal ini mereka menikmati kebebasan berpendapat dan berserikat yang dijamin demokrasi dan Konstitusi yang mereka haramkan. Di bawah lindungan demokrasi dan Pancasila mereka membangun basis komunitasnya di masjid, mushalla, dan majlis tal 'lim.

Banyak orang menyebut semua peristiwa kekerasan berbasis agama ini adalah anomali. Yakni, secara sosial-budaya dan sosial-politik tidak ada penjelasan yang memadai, karena hal ini tidak pernah terjadi sebelumnya dalam kurun waktu 50 tahun kemerdekaan bangsa Indonesia. Intoleransi dan radikalisme, apalagi terorisme tidak ada dalam tradisi bangsa Indonesia. Realitas ini tidak tampak di permukaan. Mereka tidak mungkin secara terang-terangan menyebut dirinya teroris atau radikal. Hal ini dikarenakan mereka meyakini bahwa tindakan dan cara yang dilakukannya merupakan bagian dari pengalaman ajaran agama yang harus ditunaikan. Di permukaan tidak jarang mereka menggunakan simbol dan jubah keagamaan. Ini gerakan ideologi yang bekerja dalam ruang gelap, kedap suara, tetapi sangat sistematis dan terencana secara matang.

\section{Upaya LSM dalam Pencegahan Intoleransi, Radikalisme dan Terorisme}

\section{Wahid Institute}

Wahid Institute lahir pada tanggal 7 September 2004. LSM ini merupakan lembaga yang berusaha mewujudkan keinginan intelektual Abdur- rahman Wahid (Gus Dur) yakni terciptanya pemikiran Islam moderat yang dapat mendorong terciptanya demokrasi, multikulturalisme dan toleransi di kalangan kaum muslim di Indonesia dan seluruh dunia. Kegiatan yang dibangun Wahid Institute bertujuan untuk membangun masyarakat Indonesia yang menjunjung tinggi nilai toleransi sehingga tercipta bangsa yang luhur, sejahtera, dan damai.

Kejahatan terorisme telah menyebabkan banyak orang yang tidak berdosa menjadi korban. Tindakan yang dilakukan oleh sebagian orang tersebut kerap mengatasnamakan agama, padahal tidak ada satu agama pun yang memiliki ajaran dan paham radikal apalagi tindakan terorisme. Paham agama yang dangkal dan kaku serta absennya pendekatan yang holistik dan komprehensif, mengakibatkan seseorang sangat mudah menjadi radikal dan teroris. Menurut Alam:

"radikalisme itu pandangan (partisipasi) untuk menggunakan kekerasan atas nama agama. Sekarang yang menjadi kebijakan Internasional seperti PBB yang sering menyebutkan failing extremism. Karena ingin menegaskan bahwa hukum (langkahlangkah) negara itu harus menjelaskan indikator kekerasan. Di negara liberal (Amerika atau Eropa) misalnya kenapa istilah extremism dikaitkan dengan failing, karena bagi mereka extremism itu sesuatu yang masih memungkinkan dalam pemikiran orang, yang menjadi masalah kemudian ketika menggunakan istilah kekerasan" (Wawancara dengan Alam, peneliti Wahid Institute, 2019).

Berdasarkan paparan di atas, informan memandang bahwa toleransi adalah satu sikap (tindakan) yang menghormati, mengakui hak-hak 
dasar warga negara, bahkan memperluas hak dasar tersebut. Jadi kalau terpenuhinya hak-hak dasar yang sangat beragam itu artinya toleransi telah berproses. Toleransi memiliki dimensi yang luas. Oleh karena itu, intoleransi adalah suatu tindakan yang tidak menghormati hak-hak warga negara dan merupakan pembunuhan hak-hak dasar warga negara. Informan mempunyai kerangka berfikir sebagai berikut; intoleransiradikalisme-failed extremism. Bagi informan intoleransi itu sumber dari aksi-aksi kekerasan yang mengatasnamakan agama. Menurut Alam:

"Logikanya memang tidak setiap tindakan intoleran itu akan berakhir dengan radikalisme. Tapi hampir dipastikan setiap mereka yang melakukan tindakan radikal termasuk extremism itu bermula dari intoleransi. Dalam isu radikalisme, Wahid Institute menggunakan pendekatan yang umumnya dipakai oleh Internasional "public health model" (model kesehatan masyarakat). Menurutnya ada 3 tahapan: kelompok sehat (menolak radikalisme); kelompok rentan; kelompok sakit (yang sudah melakukan tindakan radikalisme). Selain itu juga ada beberapa pendekatan: pertama, pendekatan primer (populasi umum). Kedua, pendekatan sekunder (menyasar kepada kelompokkelompok rentan). Ketiga, pendekatan tersier (yang sudah melakukan tindakan radikalisme)" (Wawancara dengan Alam, peneliti Wahid Institute, 2019).

Dalam pemahaman informan radikalisme bukan sekedar ingin merubah secara total pada kondisi kehidupan masyarakat. Penggunaan istilah radikal untuk menjelaskan gerakan kelompok Islam merujuk pada perilaku yang berupaya mengevaluasi, menentang, menolak, sistem politik yang ada seperti halnya demokrasi, negara nasionalis, serta menginginkan perubahan sesuai dengan cita-cita masyarakat Islam, dengan cara formalisasi hukum Islam melalui amandemen undang-undang. Bahkan beberapa kelompok menolak gagasan negara nasionalistik yang berlandaskan Pancasila dan ingin menggantinya dengan negara Islam, sebagaimana yang diinginkan oleh kelompok Islam radikal di Indonesia (Thoyyib 2018).

Bagi mereka Islam adalah agama dengan sistem politik yang tepat yang berperan sebagai landasan relasi yang integral antara negara dan agama. Ada juga kelompok-kelompok gerakan yang menggunakan cara-cara damai, misal dialog, diseminasi, publikasi, seminar untuk menyebarkan misi mereka. Akan tetapi ada juga gerakan yang menggunakan kekerasan seperti terlibat dalam konflik sektarian dan teror bom. Dengan demikian, terlepas dari asal-usul kelompok Islam radikal dianggap mengancam keberadaan negara nasionalis dan keamanan nasional bangsa Indonesia.

Penyebab utama lahirnya kejahatan teroris dimulai dari sikap intoleransi yang dilakukan oleh orang atau kelompok yang dangkal memahami agama. Ketika seseorang sudah bersikap intoleran terhadap perbedaan, sudah dipastikan mempunyai paham radikal. Ketika seseorang terkontaminasi dengan paham radikal yang tidak mau mengakui perbedaan dan berkeinginan mewujudkan perubahan dengan cepat, dengan menggunakan kekerasan atas nama agama yakni terorisme. Tidak menutup kemungkinan akan bermunculan peristiwa-peristiwa kejahatan merusak fasilitas umum bahkan sampai menghilangkan nyawa masyarakat sipil. Dengan demikian, perlu adanya kaunter sikap intoleransi dengan memberikan pemahaman kepada masyarakat 
bahwa perbedaan itu harus di rawat, sebarkan sikap-sikap toleransi menghargai dan menghormati perbedaan.

\section{SETARA Institute}

SETARA Institute merupakan lembaga swadaya masyarakat (LSM) yang didirikan oleh beberapa individu yang keinginan dan berdedikasi tinggi dalam persoalan kemanusiaan. Perlakuan setara dalam kehidupan bermasyarakat untuk saling menghormati keragaman, mengutamakan solidaritas dan menjunjung tinggi martabat manusia. LSM ini gencar mensosialisasikan dan mempromosikan terciptanya keadaan yang akan mengarah pada sistem politik terbuka berdasarkan penghormatan terhadap keragaman, pembelaan hak asasi manusia, dan penghapusan intoleransi serta sikap xenofobia. Sejak 5 tahun LSM ini beroperasi, setidaknya telah menghasilkan 20 laporan terkait dengan persoalan keragaman di Indonesia dan hasilnya juga banyak mendapat apresiasi.

SETARA Institute sebagai LSM meyakini bahwa suatu masyarakat demokratis akan mengalami perkembangan ketika semua elemen masyarakat tumbuh saling memahami, pengertian, penghormatan dan pengakuan terhadap keberagaman. Namun, tindakan diskriminasi dan intoleransi di tengah masyarakat masih terus berlangsung bahkan mengarah pada aksi kekerasan yang berujuang pada aksi terorisme. Langkah untuk mempererat saling menghormati dan menghargai atas keberagaman dan hak-hak manusia dengan membuka partisipasi yang lebih luas diharapkan dapat mengembangkan nilai demokrasi dan perdamaian. Menurut Coky:
"Kata radikal itu sesuatu yang ingin melakukan perubahan mendasar secara cepat. Melihat Indonesia suatu teri-tori yang pada awalnya merupakan bagian daerahdaerah yang pernah menjadi bagian dari jajahan Belanda. Meskipun Soekarno dan beberapa faunding father kita melakukan klasifikasi bahwa setelah ada kerajaan Majapahit/Sriwijaya yang areanya melintasi apa yang disebut Nusantara. Tapi bukti-bukti ilmiah menunjukkan bahwa tidak ada satu kerajaan yang bersifat imperium yang menguasai seluruh area Nusantara. Justru birokrasi Belanda yang menyatukan itu semua. Jadi bisa dikatakan Nasionalisme kita adalah nasionalisme yang berangkat dari semangat anti nasionalisme dan konsep Indonesia sendiri masih baru" (Wawancara dengan Coky, peneliti SETARA Institute, 2019).

Nasionalisme Indonesia berkembang pada awal abad 20 yang disebut nation state (negara bangsa) itu ketika proses perumusan negara bangsa pun menjadi perdebatan/tarik menarik apa yang paling tepat, ide sosial apa yang tepat untuk Indonesia. Tapi akhirnya secara aklamasi bisa diterima bahwa Pancasila sebagai ide sosial. Jadi Indonesia dan Pancasila satu kesatuan. Kalau Pancasila itu hilang, Indonesia pun akan hilang. Kalau ada gerakan-gerakan yang ingin merubah Pancasila, ingin menjadikan Indonesia sebagai negara agama, ingin agama tertentu menjadi dominan khusus dalam pranata sosial, hukum dan lainnya, ini akan berakibat integrasi sosial dan itu akan terancam. Jadi gerakan radikalisme dikonotasikan pada gerakan-gerakan yang ingin melakukan perubahan pada nilai Pancasila, Bhineka Tunggal Ika, Undang-undang Dasar 1945, dan NKRI dengan cara menjadikan Indonesia menjadi negara agama. Hal itu tidak 
melalui jalan demokrasi, bahkan menolak demokrasi.

Latar belakang atau motif dan tujuan dari tindakan-tindakan terorisme di Indonesia menurut Coky, secara nasional dapat dipetakan dalam tiga yakni, pertama, cita-cita mereka yang menginginkan mendirikan negara agama tidak pernah surut. Kedua, demokrasi bagi mereka ditafsirkan sebagai hukum manusia, bukan hukum Tuhan, maka dari itu mereka menolak demokrasi. Kalaupun kemudian mereka awalnya mungkin menyetujui ide demokrasi, tapi mereka melihat bahwa melalui demokrasi (jalur parlemen) ruang geraknya tipis untuk bisa menggunakan cita-cita mereka. Lihat dalam pemilu tahun 55 (Masyumi dan NU) masuk dalam 4 besar dalam perolehan suara, tetapi dalam konstituante mereka juga tidak bisa berhasil untuk mendesakkan agama Islam menjadi negara. Kemudian pemilu di era Orde Baru maupun reformasi partai-partai Islam tidak memperoleh suara signifikan. Dan yang terjadi adalah partai Islam sedang mengadopsi, kalau dicermati partai-partai politik di Indonesia ideologinya sama. Dengan demikian, semakin menebalkan keyakinan mereka bahwa melalui demokrasi tidak yakin berhasil. Selain itu mereka juga melihat pengalaman di luar negeri (Suriah/Mesir) dalam beberapa tahun terakhir ini melalui demokrasi, meskipun menang tidak bisa berjalan sesuai cita-citanya.

Ketiga, mereka menyadari betul bahwa memenangkan cita-cita mereka hanya bisa diperoleh oleh situasi yang tidak stabil. Kondisi politik yang permanen, mereka malah semakin tersingkirkan. Maka dari itu, mereka melakukan aksi-aksi yang menurut mereka bisa membuat rasa ketakutan di masyarakat dan ketidakstabilan politik. Dengan demikian, mereka bisa mengambil situasi-situasi. Jadi semua kembali kepada politik kekuasaan, karena mereka juga menyadari betul bahwa hanya kekuasaanlah cita-cita mereka agar negara ini menjadi negara agama bisa terwujud.

\section{Makna Deradikalisasi Menurut LSM}

\section{Wahid Institute}

Program dan kegiatan deradikalisasi menjadi andalan banyak pihak yang peduli dan konsen pada arus ancaman terorisme. Fenomena ini tidak hanya terjadi di Indonesia, tapi juga di dunia. Langkah-langkah untuk mengkaunter paham radikal bukan saja dilakukan oleh Badan Nasional Penanggulangan Terorisme (BNPT), tapi juga ormas Islam seperti NU, Muhammadiyah, dan sejumlah LSM seperti Wahid Institute. Program deradikalisasi sangat dibutuhkan, akan tetapi tidak mudah. Ada banyak tantangan di sekelilingnya dari berbagai sudut. Karena deradikalisasi sendiri dianggap kurang menekankan pencegahan dan yang tidak kalah penting yakni kontra-terorisme. Peran dan fungsi dari program deradikalisasi menurut Alam:

"Saya kira ada yang efektif ada juga yang belum efektif. Misalnya dalam beberapa hal upaya-upaya yang dilakukan oleh BNPT kita melihat masih berada pada level karitatif (deklarasi). Hal tersebut bisa memberi dampak bahwa ada gerakan, tetapi tidak cukup harus masuk pada yang lebih luas. Ada beberapa hasil yang dilakukan oleh BNPT dalam program deradikalisasi. Misalnya saja BNPT sudah melibatkan napiter dalam mengusut kasus terorisme di 
Indonesia. Tetapi masih ada program yang bersifat karitatif (deklarasi) dan seminar. Kemudian kontra narasi juga sudah dilakukan BNPT hanya saja yang menjadi PR besar adalah bagaimana ukuran keberhasilan dan melihat tingkat efektivitas keberhasilan program deradikalisasi" (Wawancara dengan Alam, peneliti Wahid Institute, 2019).

Wahid Institute misalnya melakukan kontra narasi dengan merekam, melakukan kampanye pernyataan-pernyataan dari pelaku terorisme. Selain itu juga melakukan pendekatan kepada para pelaku melalui kegiatan-kegiatan sosial (kerjasama dengan takmir masjid), misalnya dengan cara memberikan bantuan eksidental (musibah bencana alam). Yang dicari dari para teroris menurut Alam:

"Mereka mencari tempat yang tidak mudah dideteksi dan bisa memperluas jaringan. Kita tidak memiliki data yang cukup kuat mengenai terorisme. Terorisme tidak sama dengan intoleransi. Terorisme merupakan tindakan dari radikalisme atau suatu bentuk dari ektrimisme. Kemudian radikalisme itu sendiri secara umum bisa dalam bentuk kekerasan dosmetik yang tidak ada hubungan dengan terorisme. Di dalam survey nasional yang kita lihat adalah: pertama, potensi orang terpapar radikalisme. Misalnya dari riset kami ada 0,8 \% dari 1500 responden melakukan tindakan radikal. Tapi tindakan radikal itu sendiri mulai dari menyumbang pada organisasi radikal, terlibat dalam penyerangan rumah ibadah, terlibat dalam penyerangan tempat-tempat maksiat dan terlibat demonstrasi yang mengarah pada kekerasan (ini hanya beberapa indikator). Kemudian kami juga melihat tingkat dukungan orang terhadap isu-isu terorisme misalnya; apakah tindakan bom bunuh diri itu mengenai tren toleransi di Indonesia" (Wawancara dengan Alam, peneliti Wahid Institute, 2019).
Terorisme adalah ujung dari ekstrimisme yang dimulai dari intoleransi. Wahid institute melihat intoleransi muncul karena tiga faktor yang mempengaruhi langsung terhadap intoleransi adalah pertama, faktor dimana paparan informasi berisi kebencian. Kedua, pemahaman konservatif misalnya apakah potong tangan setuju/tidak, jilbab diwajibkan tidak bagi PNS, bunga bank (contoh). Radikalisme lain lagi; pertama, informasi berisi kebencian. Kedua, dukungan terhadap kelompok radikal. Ketiga, pandangan jihad sebagai aksi kekerasan.

Ketiga faktor itu mempengaruhi langsung pada radikalisme. Di sini ekonomi tidak terlalu berpengaruh banyak dalam aksi radikalisme. Wahid institute hanya fokus pada mencegah intoleransi. Selain itu, wahid institute menyadari bahwa salah satu permasalahan terbesar yang dihadapi intoleransi adalah kebencian. Jadi tugas bagaimana pemerintah/masyarakat sipil mengurangi kebencian. Misalnya saja studi mengenai bagaimana intoleransi dikalangan warga Israel terhadap warga Israel keturunan Palestina (19\%) dari warga Israel. Studi ini hendak melihat bagaimana faktor emosi hegatif di dalam intoleransi. Faktor negatif adalah persoalan kebencian, perasaan terancam, kemarahan.

\section{SETARA Institute}

Gerakan radikal Islam ini bukan gerakan domestik, melainkan gerakan yang lintas negara/gerakan transnasional banyak diinspirasi oleh negara timur tengah. Akar kenapa Islam menjadi radikal, itu karena kerakusan Amerika dan otoritarian. Sehingga menyebabkan Islam yang tadinya terbuka (moderat) menjadi keras untuk melakukan perlawanan terhadap otori- 
tarianisme dan kerakusan Amerika di Timur Tengah. Awal abad 20, Islam radikal keras semacam itu. Pergolakan politik global sangat mempengaruhi gerakan politik di Indonesia. Gerakan DI/TII misalnya tidak sekeras Islam temporer sekarang ini. Gerakan terorisme awal tahun 2000 yang dipelopori oleh DI/TII/NII tidak kemudian sekeras gerakan terorisme sekarang.

Ada generasi baru yang tidak lagi punya afiliasi dengan DI/TII/NII, bahkan tidak ada kaitanya dengan politik Islam lama. Jadi sampai kapanpun pergerakan politik global khususnya di timur tengah tafsir-tafsir Islam yang keras itu akan selalu ada dan itu akan berpengaruh kepada gerakan-gerakan Islam di Indonesia. Kemudian menjadi wajar muncul bibit-bibit baru/kelompok baru yang terderidikalisasi ini sebetulnya kelompok-kelompok lama. Proses deradikalisasi itu kelompok-kelompok yang berafiliasi dengan DI/TII/NII.

Proses deradikalisasi yang dilakukan oleh pemerintah memang harus diakui tidak terlalu signifikan. Karena memang sistem lembaga pemasyarakatan belum mempunyai kapasitas untuk program deradikalisasi. Bangsa Indonesia belum punya lapas khusus yang mempunyai program-program yang terstruktur, sekarang ini masih di tempatkan di lapas-lapas umum dan sipir di lapas tidak memiliki kemampuan soal deradikalisasi. Yang dilakukan SETARA Institute menurut Coky:

"SETARA Institute tidak masuk dalam proses tersebut, melainkan kita melakukan kaunter radikalisme. Kita melakukan pendidikan di tingkat sekolah dalam upaya penyadaran kepada masyarakat. Karena sejak awal SETARA berpandangan bahwa masyarakat 'imun' sehingga tidak terpapar oleh ide-ide semacam itu. Kita juga pernah mengundang para sipir untuk membahas program deradikalisme. Dari kegiatan tersebut jadi paham apa kekurangan-kekurangan dan yang perlu dibantu untuk program tersebut. Saya melihat tetap sulit karena lapas kita tidak dirancang untuk napi teroris. Menjadi problem juga kalau napi-napi teroris dipusatkan dalam satu lapas. Hal itu akan terjadi interaksi mereka untuk saling menguatkan" (Wawancara dengan Coky, peneliti SETARA Institute, 2019).

Proses deradikalisasi itu menurut SETARA Institute tidak kemudian merubah pola pikir, tetapi menjadikan seorang untuk percaya bahwa kekerasan itu bukan cara untuk mencapai tujuannya. Deradikalisasi juga harus melibatkan keluarga dan lingkungannya. Keluarga tentu harus diberikan kesadaran dalam persoalan hidup mereka. Begitu juga lingkungan harus ikut terlibat dalam hal menerima napiter-napiter kembali hidup bersamanya. Karena proses deradikalisasi tidak semata pada persoslan individu, tapi lingkungan sosial juga berperan aktif. Adapun yang memiliki kemampuan dalam proses deradikalisasi itu negara. Tapi negara juga harus membuka diri yang kemudian melibatkan masyarakat sipil.

Selama ini SETARA lebih fokus terhadap menyadarkan masyarakat agar imun terhadap pengaruh pandangan radikal. Oleh karena itu, yang lakukan adalah masuk ke sekolah, pendidikan formal yang didalamnya diberi isu-isu toleransi. Karena bagi SETARA percaya bahwa intoleransi adalah pertama bagi paham radikalisme. Kemudian kenapa pendidikan menjadi penting, karena demografi menunjukkan bahwa usia-usia segitu yang representatif dan potensial. Selain itu juga SETARA sedang melakukan pe- 
metaan paham radikal di kalangan mahasiswa, SETARA melakukan di ranah counter radikalisme. Ada 3 kluster yang di analisis: Intoleransiradikalisme tanpa kekerasan (terbatas)-radikalisme kekerasan. SETARA melihat bahwa Indonesia sangat kecil kemungkinan terjadi seperti halnya di Syiria dan Pakistan. Karena sejarah dan kultur berbeda, geografis sosial juga berbeda. Jadi SETARA melihat bahwa deradikalisasi itu bukan untuk merubah mindset, tetapi menutup peluang dalam melakukan aksi terorisme.

\section{Kesimpulan}

Program penanggulangan paham radikal yang berujung pada aksi teror melalui program deradikalisasi yang dilakukan pemerintah Indonesia melalui Badan Nasional Penanggulangan Teroris (BNPT) tampaknya belum berjalan secara optimal dan maksimal. Dua klasifikasi program deradikalisasi yang lakukan BPNT yakni deradikalisasi di dalam lapas maupun di luar lapas sama-sama memiliki catatan kritis. Program deradikalisasi di dalam lapas yang menekankan pada re-edukasi ideologi negara dipandang tidak efektif karena sulitnya mengubah pola fikir para nara pidana. Sementara program deradikalisasi di luar lapas kurang disiapkan secara matang sehingga hasil kerjanya kurang memberikan hasil yang signifikan. Untuk itu peran seluruh unsur masyarakat secara sinergis dibutuhkan dalam rangka penanggulangan intoleransi dan radikalisme di Indonesia.

LSM memandang bahwa proses munculnya tindakan intoleransi dan radikalisme diawali oleh informasi kebencian. Ketika informasi kebencian berpadu dengan pandangan konservatif, maka memunculkan tindakan intoleransi. Sementara informasi kebencian yang berpadu dengan dukungan kelompok radikal dan diperkuat dengan pandangan bahwa aksi kekerasan adalah jihad maka akan memunculkan radikalisme. Sikap intoleran dan radikal berkait erat. Sikap intoleran akan berkembang menjadi radikal dan bahkan terror jika tidak ditangani secara tepat. Untuk pengatasan intolerasi dan radikalisme, yang berupa program deradikalisasi bukan semata persoalan individu, akan tetapi persoalan lingkungan sosial. Oleh karena itu peran keluarga utamanya, serta masyarakat sekitar dalam mendorong sikap deradikalisme sangat penting. Program deradikalisasi yang dilakukan seluruh unsur masyarakat, yaitu pemerintah, yang dalam hal ini BNPT, LSM serta masyarakat sipil.]

\section{Daftar Pustaka}

Armenia, Resty. 2016. "BNPT: 19 Pesantren Terindikasi Ajarkan Radikalisme." CNN Indonesia, Februari 4.

Asrori, Ahmad. 2017. "Radikalisme di Indonesia: Antara Historisitas dan Antropisitas." Kalam 9(2):253-68.

Azanella, Luthfia Ayu. 2018. "Inilah Deretan Aksi Bom Bunuh Diri di Indonesia." Kompas.com, Mei 14.

Bagir, Zainal Abidin. 2018. "Laporan CRCS: Alternatif Penanganan Masalah Penodaan Agama." CRCS UGM. Diambil (https://crcs.ugm.acid/laporan-crcspenanganan-penodaan-agama/).

Bakti, Agus Surya. 2014. Merintis Jalan Mencegah Terorisme: Sebuah Bunga Rampai. Jakarta: Semarak Lautan Warna Press. 
Belarminus, Robertus. 2016. "Peran Masyarakat Sipil Membendung Radikalisasi dalam Buku 'Deradikalisasi."' Kompas.com, Februari 12.

van Bruinessen, Martin. 2002. "Genealogies of Islamic Radicalism in Post-Suharto Indonesia." South East Asia Research 10(2):117-154.

CRCS. 2017. Laporan Tahunan Kehidupan Beragama di Indonesia Tahun 2017: Kerukunan dan Penodaan Agama sebagai Alternatif Penanganan Masalah. Yogyakarta.

Dewi, Septiana Chandra. 2018. "Upaya BNPT dalam Menghadapi Ancaman Keamanan dari Kelompok Radikal ISIS (Islamic State of Iraq and Syria)." Jurnal Ilmu Hubungan Internasional 6(1):313-28.

Fealy, Greg. 2008. "Consuming Islam: Commodified Religion and Aspirational Pietism in Contemporary Indonesia." pp. 15-39 dalam Expressing Islam: Religious Life and Politics in Indonesia, diedit oleh G. Fealy dan S. White. Singapura: ISEAS-Yusof Ishak Institute.

Firdaus, Insan. 2017. "Penempatan Narapidana Teroris di Lembaga Pemasyarakatan." Jurnal Penelitian Hukum DeJure.

Halili, Halili. 2016. Supremasi Intoleransi. diedit oleh Tim Editor Setara Institute. Jakarta: Pustaka Masyarakat Setara.

Halili, Halili. 2017. "Kondisi Kebebasan Beragama di Indonesia 2016." Setara Institute, Januari 29.

Hikam, Muhammad AS. 2016. Deradikalisasi: Peran Masyarakat Sipil Indonesia Membendung Radikalisme. Jakartat: Kompas Gramedia Group.
Idris, Irfan. 2016. Membumikan Deradikalisasi: Soft Approch Model Pembinaan Terorisme dari Hulu ke Hilir secara Berkesinambungan. Jakarta: Daulat Press.

Isnawan, Fuadi. 2018. "Program Deradikalisasi Radikalisme dan Terorisme Melalui NilaiNilai Luhur Pancasila." Fikri: Jurnal Kajian Agama, Sosial dan Budaya 3(1):1-28.

Iswanto, Agus. 2018. "Membaca Kecenderungan Pemikiran Islam Generasi Milenial Indonesia." Harmoni 17(1):172-79.

Mahyani, Ahmad. 2019. "Perlindungan Hukum Anak sebagai Pelaku Terorisme." Jurnal Hukum Magnum Opus 2(1):47-54.

Munip, Abdul. 2012. "Menangkal Radikalisme Agama di Sekolah." Jurnal Pendidikan Islam 1(2):159-81.

Perkasa, Anugrah. 2016. "Kekerasan agama, 2,498 pelanggaran belum dituntaskan." Kabar24.

PPIM UIN Jakarta. 2017. "Survey PPIM: Internet, Pemerintah, dan Pembentukan Sikap Keberagamaan Generasi Z." PPIM UIN Jakarta. Diambil (https://ppim.uinjkt. ac.id/penelitian/survey-ppim-internetpemerintah-dan-pembentukan-sikapkeberagamaan-generasi-z/).

Qodir, Zuly. 2012. "Deradikalisasi Islam dalam Perspektif Pendidikan Agama." Jurnal Pendidikan Islam 2(1):85-107.

Rabasa, Angel dan Cheryl Benard. 2014. Eurojihad: Patterns of Islamist Radicali zation and Terrorism in Europe. New York: Cambridge University Press.

Rahman, Panji Futuh. 2016. "Penerapan Materi Deradikalisasi untuk Menanggulangi Radikalisme pada Ekstrakulikuler Keagamaan." Jurnal Tarbawy 3(2):154-65. 
Rauf, Abd. 2018. "Forum Kordinasi Penanggulangan Terorisme (FKPT) dan Gerakan Deradikalisasi Agama di Indonesia: Studi Kasus di Maluku." Tahkim 14(2):210-25.

Rokhmad, Abu. 2012. "Radikalisme Islam dan Upaya Deradikalisasi Paham Radikal." Walisongo: Jurnal Penelitian Sosial Keagamaan 20(1):79-114.

Rokhmad, Abu. 2014. "Pandangan Kiai tentang Deradikalisasi Paham Islam Radikal di Kota Semarang." Analisa: Journal of Social Science and Religion 21(1):27-37.

Solahudin, Solahudin. 2013. The Roots of Terrorism in Indonesia: From Darul Islam to Jem'ah Islamiyah. diedit oleh G. Fealy. New York: Cornell University Press.

Suarda, I. Gede Widhiana. 2016. "A Literature Review on Indonesia's Deradicalization Program for Terrorist Prisoners." Mimbar Hukum 28(3):526-43.

Supriadi, Endang. 2018. "Measuring the Importance of Stemming Radicalism in the Decentralization Era of Democracy." Mimbar: Jurnal Sosial dan Pembangunan 34(2):292-300.

Syahlan, Taslim. 2015. "Menangkal Gerakan Radikalisme Islam Melalui Sekolah."
Magistra: Media Pengembangan Ilmu Pendidikan Dasar dan Keislaman 6(2):1-15.

Thoyyib, Mochamad. 2018. "Radikalisme Islam Indonesia." Ta'lim: Jurnal Studi Pendidikan Islam 1(1):90-105.

Tim Liputan BBC. 2011. "Survei: Hampir 50\% Pelajar Setuju Tindakan Radikal.” $B B C$ News Indonesia, April.

Tim Liputan CNN. 2019a. "Menag: Hasil Survei, 52 Persen Pelajar Setuju Radikalisme." CNN Indonesia, November.

Tim Liputan CNN. 2019b. "Rentetan Bom dan Aksi Terorisme Selama Ramadan di Indonesia." CNN Indonesia, Juni 4.

Tim Liputan MI. 2020. "Survei Wahid Institute: Intoleransi-Radikalisme Cenderung Naik" Media Indonesia, Januari 18.

Tim Peneliti PPIM UIN Jakarta. 2017. Api dalam Sekam: Keberagaman Gen Z. Survei Nasional tentang Sikap Keberagamaan di Sekolah dan Universitas di Indonesia. Jakarta.

Zuhri, Saefudin. 2017. "Kebijakan Deradikalisasi Terorisme oleh BNPT: Perspektif Spektrum Politik." Jurnal Ilmu Kepolisian. 
This page intentionally left blank. 